\title{
FUNCTIONAL ASSESSMENT OF FREE RADIAL ARTERY FOREARM FLAP AFTER TONGUE RECONSTRUCTION FOLLOWING HEMIGLOSSECTOMY IN A TERTIARY CARE CENTRE OF CENTRAL INDIA
}

\author{
Soniya Moses ${ }^{1}$, Sachin Vermaㄹ, Nitesh Chaukikar ${ }^{3}$
}

${ }^{1}$ Associate Professor, Department of Surgery, MGM Medical College and M. Y. Hospital, Indore, Madhya Pradesh, India.

${ }^{2}$ Assistant Professor, Department of Surgery, MGM Medical College and M. Y. Hospital, Indore, Madhya Pradesh, India.

${ }^{3}$ Resident, Department of Surgery, MGM Medical College and M. Y. Hospital, Indore, Madhya Pradesh, India.

\section{ABSTRACT}

\section{BACKGROUND}

Primary closure following oncosurgical resection of ca. tongue has been found to compromise tongue function in regard to speech and swallowing very badly. In contras,t reconstruction of tongue with free radial forearm flap following oncosurgical resection has shown promising functional tongue

The aim of this study was to assess the function of tongue after hemiglossectomy and reconstruction with free radial artery forearm flap.

\section{MATERIALS AND METHODS}

30 Patients who had undergone reconstruction of tongue with FRAF flap following the hemiglossectomy or subtotal glossectomy for ca. tongue.

\section{RESULTS}

In 30 patients of tongue carcinoma, hemiglossectomy with modified radical neck dissection with radial forearm free flap reconstruction was done. After 3 months and 9 months follow up, the radial forearm free flap reconstruction in the tongue had acceptable appearance and good tongue mobility with intelligible speech on the basis of modified Washington score. The patient tongue function was improved compared to hemiglossectomised tongue.

\section{CONCLUSION}

Data obtained in the present study shows reasonable functional improvement in terms of speech, appearance, swallowing, saliva, chewing, taste, at the end of 3 months. Best functional score was not obtained at that point of time. Further during course of follow up at 9 months the improvement in tongue function was better and statistically significant.

\section{KEY WORDS}

Tongue, Free Radial Forearm Flap, Hemiglossectomy.

HOW TO CITE THIS ARTICLE: Moses S, Verma S, Chaukikar N. Functional assessment of free radial artery forearm flap after tongue reconstruction following hemiglossectomy in a tertiary care centre of central India. J. Evolution Med. Dent. Sci. 2019;8(09): 649-652, DOI: $10.14260 / \mathrm{jemds} / 2019 / 143$

\section{BACKGROUND}

Squamous cell carcinoma of tongue is a highly malignant condition and results in significant mortality and morbidity. However, early detection and treatment results in better outcome and prolongs survival. The morbidity following extensive resection of tongue results in severe speech and swallowing disturbances and life-threatening aspiration that needs reconstruction.

The ideal method of reconstruction should provide good functional and aesthetic outcome. The field of reconstructive surgery in the head-neck region is a dynamic one and has gone through numerous changes in past two decades. Microvascular free flap technique has largely replaced other techniques.1,2,3 Free flaps such as radial forearm flap and anterolateral thigh flap have become the first choice in tongue reconstruction.

'Financial or Other Competing Interest': None.

Submission 15-10-2018, Peer Review 14-02-2019,

Acceptance 22-02-2019, Published 04-03-2019.

Corresponding Author:

Dr. Nitesh Chaukikar,

C 90, Phase 2, Sagar Royal Villa,

Near Aashima Mall, Hoshangabad Road,

Bhopal-462026, Madhya Pradesh, India.

E-mail: drnits2606@gmail.com

DOI: $10.14260 /$ jemds $/ 2019 / 143$

Preservation of function including speech and swallowing, and restoration of appearance are the major goals of reconstruction.

Our technique of free radial forearm flap for reconstruction of tongue following oncosurgical resection in a series of patients could fulfil the reconstructive goals to a great extent.

The free radial forearm flap is a workhorse flap in tongue reconstruction. Its lack of extra bulk, robust vascularity, long vascular pedicle, good calibre of the vessels, relative ease of dissection, flexibility in designing and lack of significant donor site morbidity are among its main advantages. Its low flap loss and complication rate offer the best choice for reconstruction of tongue following oncosurgical resection. $4,5,6$

\section{Aim of Study}

To assess the function of tongue after reconstruction with free radial artery forearm flap following hemiglossectomy for Ca tongue.

Type of Study

Interventional study.

\section{MATERIALS AND METHODS}

The present study was conducted in the Department of SURGERY M.Y Hospital and Mahatma Gandhi Medical College, 
Indore, over a period of 18 MONTH. We enrolled 30 Patient who had undergone reconstruction of tongue with FRAF flap following the hemiglossectomy or subtotal glossectomy for Ca tongue. ${ }^{6-10}$ They fulfilled all inclusion/exclusion criteria, and all provided written informed consent for the participation. The research protocol was approved by the Institutional ethics and scientific review committee.
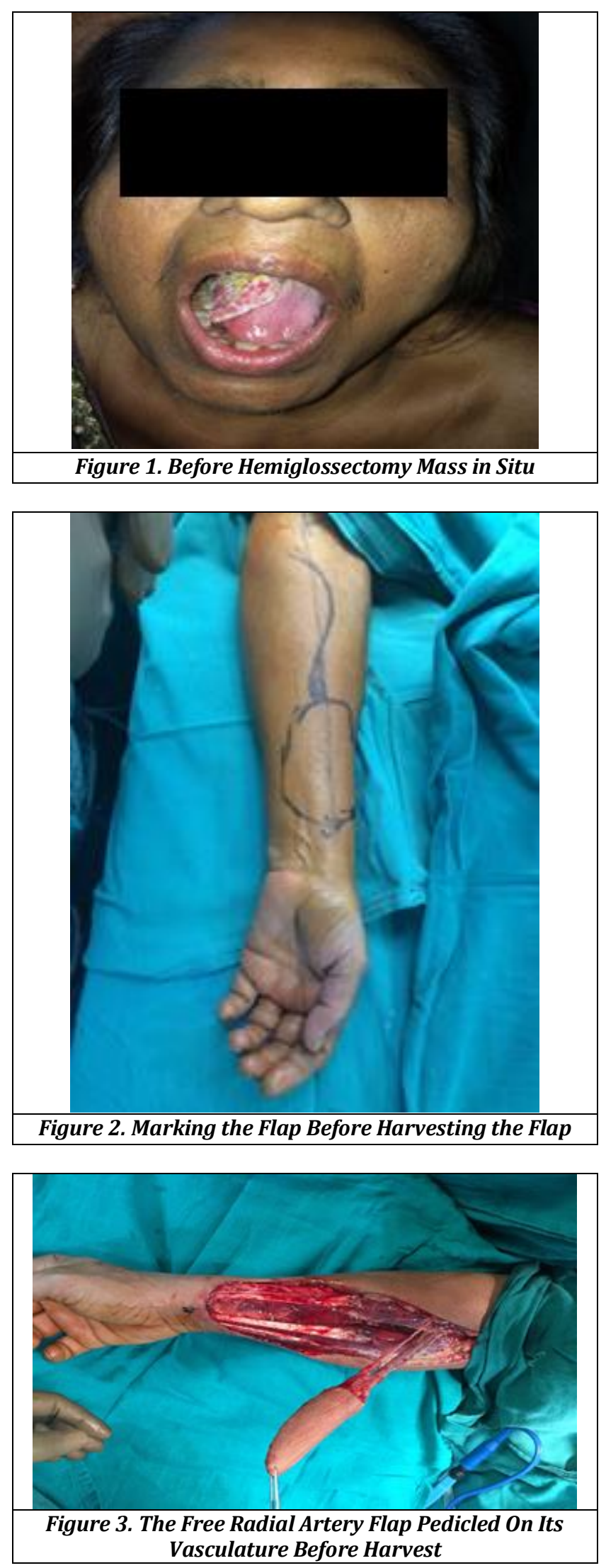

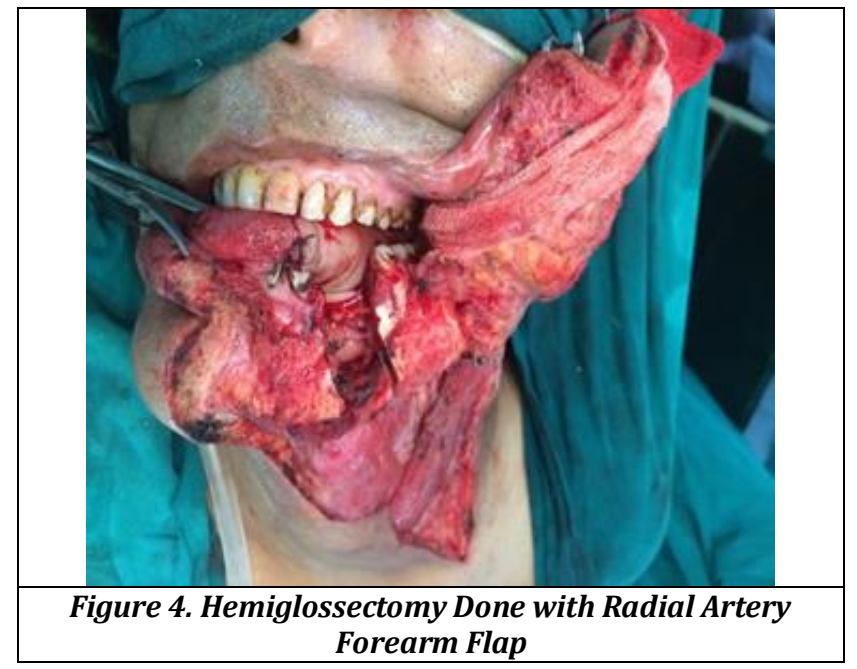

\section{Inclusion Criteria}

All patients who has undergone reconstruction of tongue with FRAF following the hemiglossectomy or subtotal glossectomy for Ca tongue \& coming to M. Y. Hospital, Indore.

\section{Exclusion Criteria}

Total glossectomy patients. Patient not reconstructed with FRAF.

Scale

Scales are used for Functional Assessment of Reconstructed Tongue with Free Radial Artery Forearm-

The modified University of Washington Questionnaire (Rogers SN and Lowe D the University of Washington quality of life (UW-QoL) scale for "Handbook of Disease Burdens and Quality of Life Measures".11-17

http://refworks.springer.com/DiseaseBurdens/ (2010)

\section{Statistical Analysis}

Statistical analysis was done using Stata version 10 (StataCorp, Texas and USA). Students' test, Chi-square test was used for categorical variables.

\section{RESULTS}

In 30 patient of tongue carcinoma, underwent hemiglossectomy with modified radical neck dissection and extended supraomohyoid neck dissection with radial forearm free flap reconstruction was done. After 3 months and 9 months follow-up, the radial forearm free flap reconstruction in the tongue had acceptable appearance and good tongue mobility with intelligible speech on the basis of modified Washington score. ${ }^{18-20}$ The patient tongue function was improved than hemiglossectomised tongue.

\begin{tabular}{|c|c|c|c|c|c|c|c|c|c|c|c|}
\hline \multirow{2}{*}{$\begin{array}{c}\text { Tongue } \\
\text { Assessment }\end{array}$} & \multirow{2}{*}{$\begin{array}{l}\text { No. of } \\
\text { Patient }\end{array}$} & \multicolumn{7}{|c|}{ Score } & \multirow{2}{*}{$\begin{array}{c}\% \\
\text { Best } \\
\text { Score }\end{array}$} & \multirow[b]{2}{*}{ Mean } & \multirow[b]{2}{*}{ SD } \\
\hline & & 0 & 25 & 30 & \multirow[t]{2}{*}{50} & \multirow[t]{2}{*}{707} & \multirow{2}{*}{\multicolumn{2}{|c|}{\begin{tabular}{c|c}
75 & 100 \\
- & -
\end{tabular}}} & & & \\
\hline Swallowing & 30 & 10 & - & 20 & & & & & $0 \%$ & 20.00 & 14.00 \\
\hline Taste & 30 & 8 & - & 22 & - & - & - & - & $0 \%$ & 22.00 & 13.2 \\
\hline Speech & 30 & 13 & - & 17 & - & - & - & - & $0 \%$ & 17.00 & 14.8 \\
\hline Saliva & 30 & 15 & - & 15 & - & - & - & - & $0 \%$ & 15.00 & 15.25 \\
\hline Appearance & 30 & 14 & 16 & - & - & - & - & - & $0 \%$ & 13.3 & 12.4 \\
\hline Chewing & 30 & 29 & 1 & - & - & - & - & - & $0 \%$ & 1.61 & 8.03 \\
\hline & 0 & & & & & & & & $n$ & & \\
\hline
\end{tabular}




\begin{tabular}{|c|c|c|c|c|c|c|c|c|c|c|c|}
\hline \multirow{2}{*}{$\begin{array}{c}\text { Tongue } \\
\text { Assessment }\end{array}$} & \multirow{2}{*}{$\begin{array}{c}\text { No. of } \\
\text { Patients }\end{array}$} & $\mathbf{0}$ & $\mathbf{2 5}$ & $\mathbf{3 0}$ & $\mathbf{5 0}$ & $\mathbf{7 0}$ & $\mathbf{7 5}$ & $\mathbf{1 0 0}$ & $\begin{array}{c}\text { Best } \\
\text { Score }\end{array}$ & Mean & SD \\
\hline Swallowing & 30 & 2 & - & 3 & - & 12 & - & 13 & $43 \%$ & 74.33 & 28.90 \\
\hline Taste & 30 & 2 & - & 6 & - & 6 & - & 16 & $53 \%$ & 73.33 & 30.8 \\
\hline Speech & 30 & 1 & - & 2 & - & 15 & -- & 12 & $40 \%$ & 77 & 24.10 \\
\hline Saliva & 30 & 2 & - & 6 & - & 6 & - & 16 & $53 \%$ & 73.33 & 33.39 \\
\hline Appearance & 30 & & 1 & - & 6 & - & 15 & 8 & 26 & 75 & 19.36 \\
\hline Chewing & 30 & 5 & - & - & 15 & - & - & 10 & 33 & 58.3 & 34.35 \\
\hline
\end{tabular}

The paired ' $t$ ' test was used to find out the difference between the swallowing at 3 months and swallowing at 9 months Mean and standard deviation of swallowing at 3 months was $20.00 \pm 14.384$ and the mean swallowing at 9 months was $73.33 \pm 29.400$. and p value obtained was 0.000 , which is significant.

\begin{tabular}{|c|c|c|c|}
\hline Study Parameter & Mean & Std. Dev. & p-Value \\
\hline Swallowing at 3 Months & 20.00 & 14.384 & \multirow{2}{*}{0.000} \\
\hline Swallowing at 9 Months & 73.33 & 29.40 & \\
\cline { 1 - 3 } &
\end{tabular}

Table 3. Comparison of Tongue Swallowing-Functional After Surgery At 3 Months And at 9 Months

The paired ' $t$ ' test was used to find out the difference between the taste at 3 months and taste at 9 months. The mean taste of at 3 months was $22.00 \pm 13.49$ and the mean taste at 9 months was $76.67 \pm 31.3$. And $p$ value obtained was 0.000 , which is significant.

\begin{tabular}{|c|c|c|c|}
\hline Study Parameter & Mean & Std. Dev. & p-Value \\
\hline Taste at 3 Months & 22.00 & 13.49 & \multirow{2}{*}{0.000} \\
\hline Taste at 9 Months & 76.67 & 31.3 & \\
\hline $\begin{array}{r}\text { Table 4. Compariso } \\
\text { Surgery at }\end{array}$ & 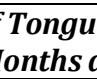 & $\begin{array}{l}\text { te-Fur } \\
\text { t } 9 \mathrm{Mo}\end{array}$ & $r$ \\
\hline
\end{tabular}

The paired ' $t$ ' test was used to find out the difference between the appearance at 3 months and appearance at 9 months Appearance at 3 months was $13.33 \pm 12.605$ and the mean Appearance at 9 months was $75.00 \pm 19.696$ and $p$ value obtained was 0.000 , which is significant.

\begin{tabular}{|c|c|c|c|}
\hline Study Parameter & Mean & Std. Dev. & p-Value \\
\hline Saliva at 3 Months & 15.00 & 15.256 & \multirow{2}{*}{.000} \\
\hline Saliva at 9 Months & 73.33 & 33.97 & \\
\hline $\begin{array}{r}\text { able 5. Compariso } \\
\text { Surgery a }\end{array}$ & n & Q $F$ & \\
\hline
\end{tabular}

Data obtained in the present study shows reasonable functional improvement in terms of speech, appearance, swallowing, saliva, chewing, taste, at the end of 3 months. Best functional score was not obtained at that point of time. Further during course of follow up at 9 month the improvement in tongue function was better and statistically significant.

\begin{tabular}{|c|c|c|c|}
\hline Study Parameter & Mean & Std. Dev. & p-Value \\
\hline Speech at 3 Months & 17.00 & 15.120 & \multirow{2}{*}{.000} \\
\hline Speech at 9 Months & 77.00 & 24.516 & \\
\hline $\begin{array}{r}\text { Table 6. Compari } \\
\text { Surgery }\end{array}$ & ang & ech-F & \\
\hline
\end{tabular}

The paired ' $t$ ' test was used to find out the difference between the saliva at 3 months and saliva at 9 months Saliva mean at 3 months was $15.00 \pm 15.256$ and the mean saliva at 9 months was $73.33 \pm 33.97$ and $p$ value obtained was 0.000 , which is significant.

\begin{tabular}{|c|c|c|c|}
\hline Study Parameter & Mean & Std. Dev. & p-Value \\
\hline Appearance at 3 Months & 13.33 & 12.685 & \multirow{2}{*}{.000} \\
\cline { 1 - 3 } Appearance at 9 Months & 75.00 & 19.696 & \\
\cline { 1 - 2 } Table 7. Comparison of Tongue Appearance-Functional \\
After Surgery at 3 Months and at 9 Months \\
\hline
\end{tabular}

The paired ' $t$ ' test was used to find out the difference between the chewing at 3 months and chewing at 9 months Chewing at 3 months was $1.67 \pm 9.129$ and the mean chewing at 9 months was $58.33 \pm 34.947$ and p value obtained was 0.000 , which is significant.

\begin{tabular}{|c|c|c|c|}
\hline Study Parameter & Mean & Std. Dev. & p-Value \\
\hline Chewing at 3 Months & 1.67 & 9.129 & \multirow{2}{*}{.000} \\
\cline { 1 - 3 } Chewing at 9 Months & 58.33 & 34.947 & \\
\hline $\begin{array}{c}\text { Table 8. Comparison of Tongue Chewing-Functional After } \\
\text { Surgery at 3 Months and at 9 Months }\end{array}$ \\
\hline
\end{tabular}

The paired ' $t$ ' test was used to find out the difference between the speech at 3 months and speech at 9 months Speech at 3 months was $17.00 \pm 15.120$ and the mean speech at 9 months was $77.00 \pm 24.516$ and $p$ value obtained was 0.000 , which is significant.

\section{DISCUSSION}

Squamous cell carcinoma of tongue typically affects men in sixth to eighth decades having a strong association with alcohol and tobacco abuse over years. Less than $4 \%$ of these lesions have been reported in patients younger than 40 years. Retrospective analysis suggested that the disease runs a more aggressive course in under- 40 age group. Metastatic spread of SCC of the tongue is facilitated by its rich lymphatic network and tends to increase with the size of the primary tumour. Approximately, $50 \%$ of tongue cancers present with neck node involvement. In order to achieve a good therapeutic control of the disease, a wide local excision and neck dissection are to be done as a primary procedure.

This oncosurgical resection results in a large threedimensional defect of the tongue and floor of the oral cavity that impairs speech, swallowing and imposes risk of aspiration. It is therefore prudent to reconstruct the defect with a well vascularised tissue for a good functional substitution. The free radial forearm flap is a workhorse flap in tongue reconstruction. Its lack of extra bulk, long vascular pedicle, good calibre of the vessels, pliability and minimal donor site morbidity are among its main advantages; the flap harvest is relatively easy and good calibre of the vessels is suitable for anastomosis with a high success rate. The free radial forearm flap, therefore, offers the best choice for reconstruction of tongue following oncosurgical resection. In our study, venous congestion occurred in one patient after 48 hours postoperatively and couldn't detect any fresh bleeding point and the flap survived. Thus, our flap survival rate was approximately $92 \%$. Song et al. reported a flap survival rate greater than 90\%; Kruse et al. reported that the success rate of free radial forearm flap was more than 95\%; Shibahara et al. ${ }^{21}$ reported a total success rate of $100 \%$. It emphasizes 
the reliability of free radial forearm flap for reconstruction of head and neck defect.

In Our study we study the functional assessment of tongue on the basis of modified Washington score we asses swallowing, taste, appearance, chewing, speech, saliva on 3 and 9 months respectively., there was a significant Chuah UC, Kamarul T, Sara T study was also shows it to be is significant. difference between the at 3 months and at 9 months, showing the effectiveness of the intervention used.

\section{CONCLUSION}

The radial forearm free flap is a viable reconstructive option for tongue defects especially where a thin, pliable flap is needed. Data obtained in the our study shows reasonable functional improvement in terms of speech, appearance, swallowing, saliva, chewing, taste, at the end of 3 months. Best functional score was not obtained at that point of time. Further, during the course of follow up at 9 month the improvement in tongue function was better and statistically significant. However, further prospective studies and quality of life assessments involving greater numbers of patients are necessary for validation of study.

\section{REFERENCES}

[1] Brown JS. T2 tongue: reconstruction of the surgical defect. Br J Oral Maxillofacial Surg 1999;37(3):194-9.

[2] Toschka $\mathrm{H}$, Feifel $\mathrm{H}$, Erli $\mathrm{HJ}$, et al. Aesthetic and functional results of harvesting radial forearm flap, especially with regard to hand function. Intern J Oral Maxillofacial Surg 2001;30(1):42-8.

[3] Skoner JM, Bascom DA, Cohen JI, et al. Short-Term functional donor site morbidity after radial forearm fasciocutaneous free flap harvest. Laryngoscope 2003;113(12):2091-4.

[4] Thawley SE, Panje WR, Batsakis JG, et al. Comprehensive management of head and neck tumors. Vol. 2. $2^{\text {nd }}$ edn. Philadelphia, PA: Saunders 1999: p. 1190.

[5] National Comprehensive Cancer Network Clinical Practice Guidelines in Oncology - Head and Neck Cancers version 2006.

[6] Moore SR, Johnson NW, Pierce AM, et al. The epidemiology of tongue cancer: a review of global incidence. Oral Diseases 2000;6(2):75-84.

[7] World Health Organization: International Agency for Research on Cancer (2008). In: Boyle P, Levin B, eds. World Cancer Report 2008. Retrieved on April 15, 2010. http://www.iarc.fr/en/publications.
[8] Yang GF, Chen PJ, Gao YZ, et al. Forearm free skin flap transplantation: a report of 56 cases. 1981. Br J Plast Surg 1997;50(3):162-5.

[9] Soutar DS, Scheker LR, Tanner NS, et al. The radial forearm flap: a versatile method for intra-oral reconstruction. Br J Plast Surg 1983;36(1):1-8.

[10] Soutar DS, McGregor IA. The radial forearm flap in intraoral reconstruction: the experience of 60 consecutive cases. Plast Reconstr Surg 1986;78(1):1-8.

[11] Ariyan S. The pectoralis major myocutaneous flap. A versatile flap for reconstruction in the head and neck Plast Reconstr Surg 1979;63(1):73-81.

[12] Schusterman MA, Miller MJ, Reece GP, et al. A single center's experience with 308 free flaps for repair of head and neck cancer defects. Plast Reconstr Surg 1994;93(3):472-80.

[13] Urken ML, Weinberg $H$, Buchbinder $D$, et al. Microvascular free flaps in head and neck reconstruction. Report of 200 cases and review of complications. Arch Otolaryngol Head Neck Surg 1994;120(6):633-40.

[14] Christie DR, Duncan GM, Glasson DW. The ulnar artery free flap: the first 7 years. Plast Reconstr Surg 1994;93(3):547-51.

[15] Wax MK, Rosenthal EL, Winslow CP, et al. The ulnar fasciocutaneous free flap in head and neck reconstruction. Laryngoscope 2002;112(12):2155-60.

[16] Wei FC, Jain V, Celik N, et al. Have we found an ideal soft-tissue flap? An experience with 672 anterolateral thigh flaps. Plast Reconstr Surg 2002;109(7):2219-30.

[17] Lyons AJ. Perforator flaps in head and neck surgery. Int J Oral Maxillofac Surg 2006;35(3):199-207.

[18] Stone M, Lundberg A. Three-dimensional tongue surface shapes of English consonants and vowels. Journal of the Acoustical Society of America 1996;99(6):3728-37.

[19] Takemoto H. Morphological analyses of the human tongue musculature for three-dimensional modeling. Journal of Speech, Language and Hearing Research 2001;44(1):95-107.

[20] Smith KK, Kier WM. Trunks, tongues, and tentacles: Moving with skeletons of muscle. American Science 1989;77(1):28-35.

[21] Richardson D, Fisher SE, Vaughan ED, et al. Radial forearm flap donor-site complications and morbidity: a prospective study. Plast Reconstr Surg 1997;99(1):109-15. 